BIOMEDICAL AND BIOSOCIAL ANTHROPOLOGY
Official Journal of the International Academy
of Integrative Anthropology
journal homepage: http://bba-journal.com

\title{
Peculiarities of organometric parameters of the coronary arteries in the perinatal period of ontogenesis
}

Herasym L. M., Slobodian O. M.

Higher State Educational Establishment of Ukraine "Bukovinian State Medical University", Chernivtsi, Ukraine

\section{ARTICLE INFO}

Received: 28 December 2018

Accepted: 31 January 2019

UDC: $611.133 .06-053.15 / .31$

CORRESPONDING AUTHOR

e-mail: slobodyanaleksandr@ukr.net Slobodian O. M.
Formation of the structure and topography of the coronary arteries during the fetal and early neonatal periods of human ontogenesis is an essential constituent while making perinatal diagnosis and understanding real parameters of the norm and pathology. Objective of the study is to determine organometric parameters of the carotid arteries during the fetal and early neonatal periods of human ontogenesis. The study was conducted on 50 specimens of dead fetuses (from 4 to 10 months) and 9 neonates (5 isolated complexes of organs in particular) by means of adequate anatomical methods: macrodissection, injection of the blood vessels, making topographic-anatomical sections, morphometry, and statistical analysis. During perinatal period external diameters and lengths of the carotid arteries are found to be characterized by two periods of an accelerated development and the period of relatively slow development. For the external diameter of the right common carotid artery and the external diameter of the left internal carotid artery the periods from the $4^{\text {th }}$ to $7^{\text {th }}$ months of the intrauterine development and the period from the $9^{\text {th }}$ month to the neonatal period are the periods of an accelerated development; the periods from the $7^{\text {th }}$ to $9^{\text {th }}$ months of development are the period of relatively slow development. The periods from the $4^{\text {th }}$ to the $7^{\text {th }}$ months of the intrauterine development and the period from the $10^{\text {th }}$ month till neonatal period are the periods of an accelerated development for the external diameter of the left common carotid artery and external diameter of the right internal carotid artery; the period from the $7^{\text {th }}$ to the $10^{\text {th }}$ months of development is the period of relatively slow development. The periods from the $4^{\text {th }}$ to the $7^{\text {th }}$ months of the intrauterine development and from the 8th month of development till the neonatal period are the periods of an accelerated development for the external diameter of the right and left external carotid arteries; the period during 7-8 ${ }^{\text {th }}$ months is the period of relatively slow development. The length of the cervical part of the right and left carotid arteries is characterized by the two periods of an accelerated development - from the $4^{\text {th }}$ to the $6^{\text {th }}$ month and from the $7^{\text {th }}$ month till the neonatal period; the period of relatively slow development is from the $6^{\text {th }}$ to the $7^{\text {th }}$ month of the intrauterine development. Comparison of the developmental periods of the carotid arteries with all the possible organometric parameters enables to affirm that practically similar enlargement of the external diameters of the common, external and internal carotid arteries both from the right and left sides is peculiar for the period of relatively slow development. The first period of an accelerated development of the carotid arteries is more specific for the external diameter and length of the left common and left external artery contrary to the second accelerated period of development of the carotid arteries. It is characterized by enlargement of the external diameters of the right common and right external carotid artery. A reliable difference of the mean values of the external diameters of the right and left common, external and internal carotid arteries is peculiar for the $4^{\text {th }}, 7^{\text {th }}, 10^{\text {th }}$ months of development and for the neonatal period for the common carotid arteries; for the external carotid arteries - the $4^{\text {th }}, 7^{\text {th }}, 9^{\text {th }}$ months of development and neonatal period; for the internal carotid arteries - for the whole months of development.

Keywords: common carotid artery, external carotid artery, internal carotid artery, morphometry, fetal and early neonatal periods of human ontogenesis. 


\section{Introduction}

Perinatal mortality with congenital developmental defects remains high (23-25\%), and mortinatality is $11-13 \%[9,14]$. Therefore, the main task of present perinatology is development of effective methods of prevention and early prenatal diagnostics of congenital pathology. Antenatal care of health of successors is impossible without substantial examination of variable factors determining physiological and pathological development of the fetus. The issue associated with finding critical periods in structural transformations of the organs and systems is not elaborated completely and it requires further studies [1-3, 6, 21].

The study conducted considerably supplements existing data concerning the structure and topography of the carotid arteries during the fetal and early neonatal period of human ontogenesis, which is an essential constituent while making perinatal diagnostics and understanding real parameters of the norm and pathology $[4,5,16,17,19,20]$. The obtained new scientifically substantiated data concerning organometric characteristic of the carotid arteries at all the stages of the perinatal period determine morphological basis and are essential to determine developmental criteria of the carotid arteries and their correspondence to the terms of gestation $[7,8,13,18]$.

Objective of the study is to determine organometric parameters of the carotid arteries during the fetal and early neonatal periods of human ontogenesis.

\section{Materials and methods}

The study was conducted on 50 specimens of dead fetuses (from 4 to 10 months) and 9 neonates (5 isolated complexes of organs in particular) without external signs of anatomical deviations or defects and without visible macroscopic deviations from the normal structure of the cardio-vascular system. The following adequate anatomical methods were applied during the study: macrodissection, injection of the blood vessels, making topographicanatomical sections, morphometry, and statistical analysis. Preserved and non-preserved dead fetuses and neonates were used for macro-dissection. The cut was made along the left median axillary line, and a thoracic part of the aorta was dissected in the posterior mediastinum. The aorta was catheterized, the catheter was inserted cranially. The injection mixture on the basis of red lead was introduced. After that sternotomy was performed, the superior vena cava was exposed and catheterized. The catheter was directed cranially, and mixture on the basis of nutrient gelatin was introduced. $5 \%$ and $10 \%$ formalin solutions were used to preserve dead fetuses and neonates: $5 \%$ solution was used for intermediate preservation of the material, and $10 \%$ solution - for the final preservation and storage of the material between the stages of the study. Micro- and macro-dissection of the structures of the major vascular-nervous cervical bundle was made by means of pincers and scissors. Dead fetuses and neonates were kept during 1-1,5 months depending on the size of an object in a special solution (24\% zinc chloride in $40 \%$ formaldehyde). Topographicanatomical sections $0,5-1,5 \mathrm{~cm}$ thick were made in one out of three planes by means of a special knife.

The obtained data were statistically processed by means of the licensed program RStudio. Null hypothesis was verified as to the fact that samples were taken from one distribution or from distributions with similar medians: $\mathrm{H}_{0}$ : \{every group has similar distribution\}; $\mathrm{H}_{1}$ : :every group does not have similar distribution\}. Student test, nonparametric Kruskal-Wallis criterion (answers the question if there is difference between the distributions of groups, but does not indicate what groups do not differ), Conover-Iman test were used to compare stochastic dominance and to obtaine results between different pair comparison after KruskalWallis test for stochastic dominance among $k$ groups. While analyzing sample coefficient of correlation $(r)$ binding force was assessed by Cheddok scale: with $r=0$ - lack of bond; with $r=$ from 0.1 to 0.3 - poor bond; $0.3-0.5$ - moderate bond; 0.5-0.7 - visible bond; 0.7-0.9 - strong bond, 0.9-1 - powerful bond. The values were considered statistically significant with $\mathrm{p}<0.05$.

The study was performed according to the major regulations of the Declaration of Helsinki as a statement of ethical principles for medical research involving human subjects (1964-2000) and the Order of the Ministry of Health of Ukraine № 690 dated 23.09.2009. The study is a fragment of a comprehensive planned initiative scientific-research work of M.G.Turkevych Department of Human Anatomy, the Department of Anatomy, Topographic Anatomy and Operative Surgery at the Higher State Educational establishment of Ukraine "Bukovinian State Medical University": "Peculiarities of Morphogenesis and Topography of the Organs and Systems during the Prenatal and Postnatal Periods of Ontogenesis" (State Registration № 0115U002769).

\section{Results}

The external diameter of the right common carotid artery (EDRCCA) during the perinatal period of ontogenesis increases from $1.562 \pm 0.051 \mathrm{~mm}$ (4-month fetuses) to $3.220 \pm 0.006 \mathrm{~mm}$ (neonatal period) (Table 1). EDRCCA increases utmost in the period from the $4^{\text {th }}$ to $7^{\text {th }}$ month of the intrauterine development and during the period from the $9^{\text {th }}$ month till neonatal period. These parameters $1.219 \mathrm{~mm}$ and $0.450 \mathrm{~mm}$ increase respectively. In the period from the $8^{\text {th }}$ to the $9^{\text {th }}$ months of development these parameters do not increase considerably. This period can be called the period of relatively slow development. According to the results of Conover-Iman test for EDRCCA, the median difference for all the possible age pairs is statistically significant, except the following pairs: "4 month - 5 month", "5 month - 6 month", "7 month - 8 month", "7 month - 10 month", "8 month - 9 month", "8 month - 10 month", "9 month - 10 month". The external diameter of the left common carotid artery (EDLCCA) 
Table 1. External diameter of the common carotid arteries during the perinatal period of ontogenesis $(\mathrm{mm})$.

\begin{tabular}{|c|c|c|c|c|}
\hline \multirow{2}{*}{$\begin{array}{c}\text { Age } \\
\text { group }\end{array}$} & \multicolumn{3}{|c|}{ External diameter of the common carotid arteries } \\
\cline { 2 - 5 } & \multicolumn{2}{|c|}{ right } & \multicolumn{2}{c|}{ left } \\
\cline { 2 - 5 } & $\mathrm{M} \pm \mathrm{m}$ & $\begin{array}{c}\text { Confidence } \\
\text { limits }\end{array}$ & $\mathrm{M} \pm \mathrm{m}$ & $\begin{array}{c}\text { Confidence } \\
\text { limits }\end{array}$ \\
\hline 4 month & $1.562 \pm 0.051$ & $1.421-1.703$ & $1.322 \pm 0.072$ & $1.141-1.503$ \\
\hline 5 month & $1.917 \pm 0.132$ & $1.594-2.240$ & $1.790 \pm 0.233$ & $1.233-2.341$ \\
\hline 6 month & $2.202 \pm 0.143$ & $1.881-2.522$ & $1.964 \pm 0.083$ & $1.774-2.153$ \\
\hline 7 month & $2.782 \pm 0.062$ & $2.653-2.911$ & $2.527 \pm 0.081$ & $2.331-2.723$ \\
\hline 8 month & $2.690 \pm 0.111$ & $2.410-2.971$ & $2.517 \pm 0.114$ & $2.243-2.790$ \\
\hline 9 month & $2.602 \pm 0.052$ & $2.473-2.730$ & $2.470 \pm 0.121$ & $2.221-2.712$ \\
\hline 10 month & $2.778 \pm 0.071$ & $2.612-2.944$ & $2.372 \pm 0.043$ & $2.270-2.473$ \\
\hline Neonates & $3.221 \pm 0.006$ & $3.090-3.351$ & $2.876 \pm 0.041$ & $2.771-2.960$ \\
\hline
\end{tabular}

Table 2. External diameter of the external carotid arteries during perinatal period of ontogenesis $(\mathrm{mm})$.

\begin{tabular}{|c|c|c|c|c|}
\hline \multirow{2}{*}{$\begin{array}{c}\text { Age } \\
\text { group }\end{array}$} & \multicolumn{3}{|c|}{ External diameter of the external carotid arteries } \\
\cline { 2 - 5 } & \multicolumn{2}{|c|}{ right } & \multicolumn{2}{c|}{ left } \\
\cline { 2 - 5 } & $\mathrm{M} \pm \mathrm{m}$ & $\begin{array}{c}\text { Confidence } \\
\text { limits }\end{array}$ & $\mathrm{M} \pm \mathrm{m}$ & $\begin{array}{c}\text { Confidence } \\
\text { limits }\end{array}$ \\
\hline 4 month & $0.848 \pm 0.005$ & $0.711-0.985$ & $0.683 \pm 0.044$ & $0.581-0.784$ \\
\hline 5 month & $1.360 \pm 0.205$ & $0.880-1.831$ & $1.247 \pm 0.232$ & $0.693-1.801$ \\
\hline 6 month & $1.640 \pm 0.105$ & $1.391-1.880$ & $1.568 \pm 0.082$ & $1.374-1.762$ \\
\hline 7 month & $2.138 \pm 0.045$ & $2.030-2.245$ & $1.937 \pm 0.034$ & $1.861-2.012$ \\
\hline 8 month & $1.990 \pm 0.050$ & $1.864-2.112$ & $1.833 \pm 0.105$ & $1.591-2.074$ \\
\hline 9 month & $2.273 \pm 0.045$ & $2.164-2.381$ & $2.070 \pm 0.030$ & $1.982-2.152$ \\
\hline 10 month & $2.567 \pm 0.072$ & $2.163-2.971$ & $2.630 \pm 0.071$ & $2.453-2.804$ \\
\hline Neonates & $3.202 \pm 0.055$ & $3.092-3.311$ & $3.016 \pm 0.053$ & $2.910-3.122$ \\
\hline
\end{tabular}

during this period of development increases from $1.322 \pm 0.072 \mathrm{~mm}$ in 4-month fetuses to $2.876 \pm 0.041 \mathrm{~mm}$ in the neonatal period (Table 1). Intensive increase of EDLCCA during the perinatal period occurs from the $4^{\text {th }}$ to the $7^{\text {th }}$ months of the intrauterine development, and from the 10th month till neonatal period. They $1.205 \mathrm{~mm}$ and $0.504 \mathrm{~mm}$ increase respectively. The period from the $7^{\text {th }}$ month to the $10^{\text {th }}$ month of development for EDLCCA is the period of relatively slow development. Conover-Iman test demonstrated that median difference for EDLCCA in all the age pairs is statistically significant, except pairs "4 month - 5 month", "4 month - 6 month", "5 month - 6 month", "7 month - 8 month", "7 month - 9 month", "8 month - 9 month", "7 month - 10 month", "8 month - 10 month", "9 month - 10 month".

The external diameter of the right external carotid artery (EDRECA) during the perinatal period of ontogenesis increases from $0.848 \pm 0.005 \mathrm{~mm}$ (4-month fetuses) to $3.202 \pm 0.055 \mathrm{~mm}$ (neonatal period) (Table 2). An intensive increase of EDRECA during the perinatal period is peculiar from the $4^{\text {th }}$ to the $7^{\text {th }}$ month of the intrauterine development, and from the $8^{\text {th }}$ month of development till the neonatal period. These organometric parameters $1.290 \mathrm{~mm}$ and $1.212 \mathrm{~mm}$ increase respectively. The period of 7-8 months is a period of relatively slow development for EDRECA. According to the results of Conover-Iman test for EDRECA the median difference for all the possible age pairs is statistically significant, except the pair " 5 month - 6 month". The external diameter of the left external carotid artery (EDLECA) during this age period increases from $0.683 \pm 0.044 \mathrm{~mm}$ in the 4 month fetuses to $3.016 \pm 0.053 \mathrm{~mm}$ during the neonatal period (Table 2). EDLECA parameters experience the largest increase from the 4th to the 7th months of the intrauterine development, and from the 8th month of development to the neonatal period. These organometric parameters $1.254 \mathrm{~mm}$ and $1.183 \mathrm{~mm}$ increase respectively. The period of a relatively slow development for EDLECA is from the 7th to the 8th month of development. Conover-Iman test demonstrated that median difference for EDLECA in all the possible age pairs is statistically significant except the pairs "5 month - 6 month", "7 month - 8 month".

The external diameter of the right internal carotid artery (EDRICA) during the perinatal period increases from $0.662 \pm 0.051 \mathrm{~mm}$ (4-month fetuses) to $2.202 \pm 0.060 \mathrm{~mm}$ (neonatal period) (Table 3). An intensive increase of EDRICA parameters is peculiar for the periods from the 4 th to the $7^{\text {th }}$ months of the intrauterine development, and from the $10^{\text {th }}$ month of development to the neonatal period. These parameters $1.198 \mathrm{~mm}$ and $0.300 \mathrm{~mm}$ increase respectively. The period of relatively slow EDRICA development is from the $7^{\text {th }}$ to the $10^{\text {th }}$ months of development. According to the results of Conover-Iman test for EDRICA the median difference is statistically significant for the pairs formed with the groups "4 months" and "neonates". For all the other age pairs there is no a considerable difference between medians. The external diameter of the left internal carotid artery (EDLICA) at this age period increases from $0.762 \pm 0.071 \mathrm{~mm}$ (4-month fetuses) to $2.271 \pm 0.055 \mathrm{~mm}$ (neonatal period) (Table 3 ). EDLICA is characterized by the two periods of an accelerated development: from the $4^{\text {th }}$ to the $7^{\text {th }}$ months of the intrauterine development, and from the $9^{\text {th }}$ month of development till the neonatal period. The parameters 1.055 and $0.319 \mathrm{~mm}$ increase respectively. The period of relatively slow development is from the $7^{\text {th }}$ to the $9^{\text {th }}$ months. Conover-Iman test demonstrated that median difference for EDLICA in all the age pairs is statistically significant, except the pairs "4 month - 5 month", "5 month 6 month", "7 month - 8 month", "7 month - 9 month", "8 month - 9 month", "8 month - 10 month", "9 month - 10 month".

The length of the cervical part of carotid arteries (distance between the point of origin of the common carotid arteries from the subclavicular arteries to the point of intersection of the external and internal carotid arteries with the stylohyoid muscles) during the perinatal period of ontogenesis increases from $19.40 \pm 0.58 \mathrm{~mm}$ (4-month fetuses) to $38.60 \pm 0.28 \mathrm{~mm}$ (neonatal period) in the right (Table 4), and from $19.70 \pm 0.37 \mathrm{~mm}$ to $40.13 \pm 0.48 \mathrm{~mm}$ in the left (Table 4). The length of the cervical part of the right and left carotid 
Table 3. External diameter of the internal carotid arteries during the perinatal period of ontogenesis $(\mathrm{mm})$.

\begin{tabular}{|c|c|c|c|c|}
\hline \multirow{3}{*}{$\begin{array}{l}\text { Age } \\
\text { group }\end{array}$} & \multicolumn{4}{|c|}{ External diameter of the internal carotid arteries } \\
\hline & \multicolumn{2}{|c|}{ right } & \multicolumn{2}{|c|}{ left } \\
\hline & $\mathrm{M} \pm \mathrm{m}$ & $\begin{array}{l}\text { Confidence } \\
\text { limits }\end{array}$ & $\mathrm{M} \pm \mathrm{m}$ & $\begin{array}{l}\text { Confidence } \\
\text { limits }\end{array}$ \\
\hline 4 month & $0.662 \pm 0.051$ & $0.523-0.802$ & $0.762 \pm 0.071$ & $0.571-0.953$ \\
\hline 5 month & $1.360 \pm 0.272$ & $0.691-2.024$ & $1.239 \pm 0.142$ & $0.888-1.589$ \\
\hline 6 month & $1.553 \pm 0.133$ & $1.254-1.852$ & $1.593 \pm 0.075$ & $1.433-1.752$ \\
\hline 7 month & $1.860 \pm 0.113$ & $1.611-2.104$ & $1.817 \pm 0.062$ & $1.683-1.951$ \\
\hline 8 month & $1.763 \pm 0.166$ & $1.373-2.152$ & $1.930 \pm 0.122$ & $1.625-2.233$ \\
\hline 9 month & $1.802 \pm 0.161$ & $1.382-2.222$ & $1.952 \pm 0.041$ & $1.843-2.061$ \\
\hline 10 month & $1.902 \pm 0.081$ & $1.722-2.081$ & $2.042 \pm 0.040$ & $1.951-2.133$ \\
\hline Neonates & $2.202 \pm 0.060$ & $2.060-2.344$ & $2.271 \pm 0.055$ & $2.158-2.383$ \\
\hline
\end{tabular}

Таблиця 4. Length of the cervical part of the carotid arteries during the perinatal period of ontogenesis $(\mathrm{mm})$.

\begin{tabular}{|c|c|c|c|c|}
\hline \multirow{2}{*}{$\begin{array}{c}\text { Age } \\
\text { group }\end{array}$} & \multicolumn{2}{|c|}{ Length of the cervical part of the carotid arteries } \\
\cline { 2 - 5 } & $\mathrm{M} \pm \mathrm{m}$ & $\begin{array}{c}\text { Confidence } \\
\text { limits }\end{array}$ & $\mathrm{M} \pm \mathrm{m}$ & $\begin{array}{c}\text { Confidence } \\
\text { limits }\end{array}$ \\
\cline { 2 - 5 } & $17.79-21.01$ & $19.70 \pm 0.37$ & $18.66-20.74$ \\
\hline 4 month & $19.40 \pm 0.58$ & $17.81-29.88$ & $29.09 \pm 1.14$ & $26.31-31.86$ \\
\hline 5 month & $27.34 \pm 1.04$ & $24.81-29$ & \multicolumn{2}{c|}{ left } \\
\hline 6 month & $29.94 \pm 0.43$ & $28.93-30.95$ & $31.31 \pm 0.52$ & $30.08-32.54$ \\
\hline 7 month & $28.76 \pm 0.53$ & $27.52-29.99$ & $30.51 \pm 0.38$ & $29.63-31.39$ \\
\hline 8 month & $34.80 \pm 0.85$ & $32.72-36.88$ & $34.34 \pm 0.78$ & $32.43-36.25$ \\
\hline 9 month & $35.05 \pm 0.51$ & $33.75-36.35$ & $36.3 \pm 0.42$ & $35.21-37.39$ \\
\hline 10 month & $36.87 \pm 0.28$ & $36.18-37.56$ & $37.37 \pm 0.56$ & $36.01-38.74$ \\
\hline Neonates & $38.60 \pm 0.28$ & $37.95-39.25$ & $40.13 \pm 0.48$ & $39.03-41.24$ \\
\hline
\end{tabular}

arteries is characterized by the two periods of an accelerated development $\left(4^{\text {th }}-6^{\text {th }}\right.$ months of development, and from the $7^{\text {th }}$ month - the neonatal period), and the period of relatively slow development (from the 6 th to the $7^{\text {th }}$ months of the intrauterine development). Conover-Iman test demonstrated that median difference for the length of the cervical part of the carotid arteries in all the age pairs is statistically significant, except the pairs " 5 month - 7 month", " 6 month - 7 month", "8 month - 9 month", which is peculiar for the length of the cervical part of the right carotid artery, and the pairs " 5 month - 6 month", "5 month - 7 month", "6 month - 7 month", "8 month - 9 month" - for the left carotid artery.

Making the correlation analysis between all the organometric parameters of the external diameters and lengths of the carotid arteries during the perinatal period of ontogenesis we have determined that the values of all the pair correlation coefficients are positive and rather close to 1 $(>0,84)$, which is indicative of a close positive relation between all the organometric parameters.

\section{Discussion}

The conducted statistical analysis for comparison of all the mean values of the external diameters of the right and left common, external and internal carotid arteries resulted in determination of reliable $(p<0.05)$ differences: for the $4^{\text {th }}$, $7^{\text {th }}, 10^{\text {th }}$ months of development and for the neonatal period for the common carotid arteries; for the $4^{\text {th }}, 7^{\text {th }}, 9^{\text {th }}$ months of development and the neonatal period for the external carotid arteries; as well as for all the months of development for the internal carotid arteries, which is indicative of a considerable difference of mean values of the external diameters of the above arteries. Certain data concerning organometric parameters of the carotid arteries are found in scientific works by Lo A. et al. [10], Naritomo M. et al. [11], Pfeiffer J., Ridder G. J. [12], Sehirli O. S. et al. [15].

In early fetuses (4-5-month) organometric parameters of the external diameter of the left common artery increase more in comparison with the right artery; in 6-7-month fetuses these sizes of the right and left arteries increase practically similar; late fetuses (8-10-month) and the neonatal period are characterized by prevailing increase of the external diameters of the right common carotid artery in comparison with the left one.

During the perinatal period of ontogenesis the external diameter of the external carotid arteries is characterized by enlargement of these parameters in the early fetuses in the left; in 6-7-month fetuses - in the right; for late fetuses and neonates - the parameters increase practically similar both in the right and left.

Organometric parameters of the external diameter of the right internal carotid artery increase more during the perinatal period of ontogenesis contrary to the left internal carotid artery.

The length of the cervical part of the carotid arteries increase more in the left in the 4-5 and 8-10-month fetuses and neonates in comparison with the length of the right carotid artery. In 6-7-month fetuses these parameters increase practically similar from both the right and left sides.

During perinatal period external diameters and lengths of the carotid arteries are found to be characterized by two periods of an accelerated development and the period of relatively slow development. Having compared the periods of development of the carotid arteries with all the possible organometric parameters we can suggest that practically similar enlargement of the external diameters of the common, external and internal carotid arteries both from the right and left are peculiar for the period of relatively slow development. The first period of an accelerated development of the carotid arteries is more specific for the external diameter and length of the common and left external carotid arteries contrary to the second accelerated period, which is characterized by more accelerated enlargement of the external diameters of the right common and right external carotid arteries.

\section{Conclusions}

1. During perinatal period external diameters and lengths of the carotid arteries are found to be characterized by two periods of an accelerated development and the period of relatively slow development. For the external 
diameter of the right common carotid artery and the external diameter of the left internal carotid artery the periods from the $4^{\text {th }}$ to $7^{\text {th }}$ months of the intrauterine development and the period from the $9^{\text {th }}$ month to the neonatal period are the periods of an accelerated development; the periods from the $7^{\text {th }}$ to $9^{\text {th }}$ months of development are the period of relatively slow development. The periods from the $4^{\text {th }}$ to the $7^{\text {th }}$ months of the intrauterine development and the period from the $10^{\text {th }}$ month till neonatal period are the periods of an accelerated development for the external diameter of the left common carotid artery and external diameter of the right internal carotid artery; the period from the $7^{\text {th }}$ to the $10^{\text {th }}$ months of development is the period of relatively slow development. The periods from the $4^{\text {th }}$ to the $7^{\text {th }}$ months of the intrauterine development and from the $8^{\text {th }}$ month of development till the neonatal period are the periods of an accelerated development for the external diameter of the right and left external carotid arteries; the period during 7$8^{\text {th }}$ months is the period of relatively slow development. The length of the cervical part of the right and left carotid arteries is characterized by the two periods of an accelerated development - from the $4^{\text {th }}$ to the $6^{\text {th }}$ month and from the $7^{\text {th }}$ month till the neonatal period; the period of relatively slow

\section{References}

[1] Akhtemiichuk, Yu. T. (2012). Topicality of scientific studies in the field of perinatal anatomy. Neonatology, Surgery and Perinatal Medicine, 2(1), 15-21.

[2] Akhtemiichuk, Yu. T., Slobodian, O. M., \& Lavriv, L. P. (2014). Prenatal development of organs and body structures. Experimental and Clinical Medicine, 3, 18-21.

[3] Akhtemiichuk, Yu. T., Slobodian, O. M., Proniaiev, D. V., \& Tovkach, Yu. V. (2014). Prenatal morphogenetic regulations of certain internal organs. Thesis in the collection of the materials of the International Scientific-Practical Conference devoted to the 100th anniversary of birth of Prof. Z.I. Ibragimova "Macromicroscopic anatomy of the organs and systems in the norm, experiment and pathology", Vitebsk (p. 31-33). Vitebsk: VSMU.

[4]Alekhin, D. I., Kurenkov, E. L., Kudrina, A. V., Kokorishvili, M. A., Goloshhapova, Zh. A., \& Karaseva, R. S. (2010). Clinically important defects of the carotid arteries. I.I. Grekov Herald of Surgery, 169(6), 11-16.

[5] Chuchin, M. Yu., Ushakova, L. V., \& Komarova, I. B. (2009). Dissection of the neck and head vessels as a cause of ischemic stroke in childhood. Pediatrics, 88(5), 22-27.

[6] Katori, Y., Kawase, T., Ho Cho, K., Abe, H., Rodriguez-V?ázquez, J. F., Murakami, G., \& Fujimiya, M. (2013). Suprahyoid neck fascial configuration, especially in the posterior compartment of the parapharyngeal space: A histological study using late?stage human fetuses. Clinical anatomy, 26(2), 204-212. doi: 10.1002/ca.22088

[7] Khasanov, A. A., Marapov, D. I., \& Shhegurova, D. I. (2007). Application of preventive methods of congenital developmental defects of the fetus. Kazan Medical Journal, 88(4), 331-336.

[8] Kiritsi, O., Noussios, G., Tsitas, K., \& Lappas, D. (2012). Unilateral agenesis of the internal carotid artery presented as transient ischaemic attack: a case report. Surgical and radiologic anatomy, 34(5), 475-477. doi: 10.1007/s00276-011-0901-z

[9] Lekhan, V. M, \& Hinzburh, V. G. (2012). Perinatal mortality in Ukraine: achievements and problems. National Health, 1, 15- development is from the $6^{\text {th }}$ to the $7^{\text {th }}$ month of the intrauterine development.

2. Having compared the periods of development of the carotid arteries with all the possible organometric parameters we can suggest that practically similar enlargement of the external diameters of the common, external and internal carotid arteries both from the right and left are peculiar for the period of relatively slow development. The first period of an accelerated development of the carotid arteries is more specific for the external diameter and length of the common and left external carotid arteries contrary to the second accelerated period, which is characterized by more accelerated enlargement of the external diameters of the right common and right external carotid arteries.

3. A reliable difference of the mean values of the external diameters of the right and left common, external and internal carotid arteries is peculiar for the $4^{\text {th }}, 7^{\text {th }}, 10^{\text {th }}$ months of development and for the neonatal period for the common carotid arteries; for the external carotid arteries - the $4^{\text {th }}, 7^{\text {th }}$, $9^{\text {th }}$ months of development and neonatal period; for the internal carotid arteries - for the whole months of development.

25.

[10] Lo, A., Oehley, M., Bartlett, A., Adams, D., Blyth, P., \&Al?Ali, S. (2006). Anatomical variations of the common carotid artery bifurcation. ANZ journal of surgery, 76(11), 970-972. doi: 10.1111/j.1445-2197.2006.03913.x

[11] Miyake, N., Hayashi, S., Kawase, T., Cho, B. H., Murakami, G., Fujimiya, M., \& Kitano, H. (2010). Fetal anatomy of the human carotid sheath and structures in and around it. The Anatomical Record: Advances in Integrative Anatomy and Evolutionary Biology, 293(3), 438-445. doi: 10.1002/ar.21089

[12] Pfeiffer, J., \& Ridder, G. J. (2008). A clinical classification system for aberrant internal carotid arteries. The Laryngoscope, 118(11), 1931-1936. doi: 10.1097/ MLG.0b013e318180213b

[13] Pokrovskij, A. V., Beloyarczev, D. F., \& Ady` rkhaev, Z. A. (2011). Direct results of reconstructive surgery with pathologic deformity of the internal carotid artery. Angiology and vascular surgery, 17(4), 91-97.

[14] Pryimak, S. G. (2013). Application of methods to prevent congenital developmental defects of the fetus. Neonatology, Surgery and Perinatal Medicine, 3(4), 89-91.

[15] Şehirli, Ü. S., Yalin, A., Tulay, C. M., Cakmak, Y. O., \& Gürdal, E. (2005). The diameters of common carotid artery and its branches in newborns. Surgical and radiologic anatomy, 27(4), 292-296. doi: 10.1007/s00276-005-0322-y

[16] Shoja, M. M., Loukas, M., Tubbs, R. S., D'Antoni, A., DiLandro, A., \& Curé, J. K. (2012). An aberrant cerebellar artery originating from the internal carotid artery. Surgical and radiologic anatomy, 34(3), 285-288. doi: 10.1007/s00276-0110891-x

[17] Timina, I. E., Burczeva, E. A., \& Losik, I. A. (2011). Present approach to a comprehensive ultrasound examination of patients with pathologic deformity of the internal carotid artery. Angiology and vascular surgery, 17(3), 49-57.

[18] Togay-Isikay, C., Kim, J., Betterman, K., Andrews, C., Meads, 
D., Tesh, P., ... \& Oztuna, D. (2005). Carotid artery tortuosity, kinking, coiling: stroke risk factor, marker, or curiosity?. Acta neurologica belgica, 105(2), 68-72. PMID: 16076059

[19] Wang, R., Snoey, E. R., Clements, R. C., Hern, H. G., \& Price, D. (2006). Effect of head rotation on vascular anatomy of the neck: an ultrasound study. The Journal of emergency medicine, 31(3), 283-286. doi: 10.1016/ j.jemermed.2005.12.026

[20] Wippold, F. J. (2007). Head and neck imaging: the role of CT and MRI. Journal of Magnetic Resonance Imaging: An Official Journal of the International Society for Magnetic Resonance in Medicine, 25(3), 453-465. doi: 10.1002/jmri.20838

[21] Znamens`ka, T. K., Bojchuk, T. M., \& Godovanecz', Yu. D. (2013). National project "New life. New quality of maternity and childhood care": innovations of scientific support and medical education. Neonatology, Surgery and Perinatal Medicine, 3(1), 13-18.

\section{ОСОБЛИВОСТІ ОРГАНОМЕТРИЧНИХ ПАРАМЕТРІВ СОННИХ АРТЕРІЙ В ПЕРИНАТАЛЬНОМУ ПЕРІОДІ ОНТОГЕНЕЗУ Герасим Л. М., Слободян О. М.}

Становлення будови і топографії сонних артерій у плодовому та ранньому неонатальному періодах онтогенезу людини є необхінню складовою під час проведення перинатальної діагностики та розуміння фактичних даних норми і патології. Мета дослідження - встановити органометричні параметри сонних артерій впродовж плодового і раннього неонатального періодів онтогенезу людини. Дослідження проведено на 50 препаратах трупів плодів (від 4 до 10 місяців) та 9 новонароджених (зокрема, 5 ізольованих органокомплексів) за допомогою адекватних анатомічних методів: макропрепарування, ін'єкція кровоносних судин, виготовлення топографоонатомічних зрізів, морфометрія та статистичний аналіз. Встановлено, що впродовж перинатального періоду для зовнішніх діаметрів і довжин сонних артерій характерні два періоди прискореного розвитку і період відносно сповільненого розвитку. Для зовнішнього діаметра правої загальної сонної артерії та для зовнішнього діаметра лівої внутрішньої сонної артерії з 4-го по 7-ий місяць внутрішньоутробного розвитку та у період з 9го місяця до періоду новонародженості - періоди прискореного розвитку; з 7-го по 9-й місяці розвитку - період відносно сповільненого розвитку. Для зовнішнього діаметра лівої загальної сонної артерії та для зовнішнього діаметра правої внутрішньої сонної артерії з 4-го по 7-й місяць внутрішньоутробного розвитку та у період з 10 місяця до періоду новонародженості - періоди прискореного розвитку; з 7-го по 10 місяці розвитку - період відносно сповільненого розвитку. Для зовнішнього діаметра правої і лівої зовнішніх сонних артерій з 4-го по 7-й місяці внутрішньоутробного розвитку та з 8-го місяця розвитку до періоду новонародженості - періоди прискореного розвитку; впродовж 7-8 місяців - період відносно сповільненого розвитку. Для довжин шийної частини правої і лівої сонних артерій притаманні два періоду прискореного розвитку - з 4-го по 6-й місяць розвитку та з 7-го місяця розвитку до періоду новонародженості; період відносного сповільненого розвитку - з 6-го по 7-й місяць внутрішньоутробного розвитку. За умов порівняння періодів розвитку сонних артерій зі всіма можливими їх органометричними параметрами можна стверджувати, що майже однакове збільшення зовнішніх діаметрів загальної, зовнішньої та внутрішньої сонних артерій як справа так і зліва є характерним для періоду відносно сповільненого розвитку. Перший період прискореного розвитку сонних артерій більш притаманний для зовнішнього діаметра і довжини лівої загальної та лівої зовнішньої артерії на противагу другому прискореному періоду розвитку сонних артерій, для якого $\epsilon$ характерне збільшення зовнішніх діаметрів правої загальної та правої зовнішньої сонної артерії. Значима різниця середніх значень зовнішніх діаметрів правої і лівої загальних, зовнішніх та внутрішніх сонних артерій характерна для 4-го, 7-го, 10-го місяців розвитку та для періоду новонародженості для загальних сонних артерій; для зовнішніх сонних артерій - для 4-го, 7-го, 9-го місяців розвитку та для періоду новонародженості; для внутрішніх сонних артерій - для всіх місяців розвитку.

Ключові слова: загальна сонна артерія, зовнішня сонна артерія, внутрішня сонна артерія, морфометрія, плодовий та ранній неонатальний періоди онтогенезу людини.

\section{ОСОБЕННОСТИ ОРГАНОМЕТРИЧЕСКИХ ПАРАМЕТРОВ СОННЫХ АРТЕРИЙ В ПЕРИНАТАЛЬНОМ ПЕРИОДЕ ОНТОГЕНЕЗА Герасим Л. Н., Слободян А. Н.}

Становление строения и топографии сонных артерий в плодовом и раннем неонатальном периодах онтогенеза человека является необходимой составляющей при проведение перинатальной диагностики и понимания фактических данных нормы и патологии. Цель исследования - установить органометрические параметры сонных артерий в течение плодового и раннего неонатального периодов онтогенеза человека. Исследование проведено на 50 препаратах трупов плодов (от 4 до 10 месяцев) и 9 новорожденных (в частности, 5 изолированных органокомплексов) с помощью адекватных анатомических методов: макропрепарирование, инъекция кровеносных сосудов, изготовление топографоанатомических срезов, морфометрия и статистический анализ. Установлено, что в течение перинатального периода для наружных диаметров и длины сонных артерий характерны два периода ускоренного развития и период относительного замедленного развития. Для внешнего диаметра правой общей сонной артерии и для внешнего диаметра левой внутренней сонной артерии с 4-го по 7-й месяц внутриутробного развития и в период с 9-го месяца по период новорожденности - периоды ускоренного развития; с 7-го по 9-й месяи развития - период относительного замедленного развития. Для наружного диаметра левой общей сонной артерии и для внешнего диаметра правой внутренней сонной артерии с 4-го по 7-й месяц внутриутробного развития и в период с 10 месяца по период новорожденности - периоды ускоренного развития; с 7-го по 10 месяц развития - период относительного замедленного развития. Для внешнего диаметра правой и левой внешних сонных артерий с 4-го по 7-й месяц внутриутробного развития и с 8-го месяца развития по период новорожденности - периоды ускоренного развития; в течение 7-8 месяца - период относительно замедленного развития. Для длины шейной части правой и левой сонной артерии присущи два периода ускоренного развития - с 4-го по 6-й месяи развития и с 7-го месяца развития по период новорожденности; период относительного замедленного развития - с 6-го по 7-й месяц внутриутробного развития. В условиях сравнения периодов развития сонных артерий со всеми возможными их органометрическими параметрами 
можно утверждать, что почти одинаковое увеличение наружных диаметров общей, внешней и внутренней сонных артерий как справа так и слева характерно для периода относительно замедленного развития. Первый период ускоренного развития сонных артерий более присущий для внешнего диаметра и длины левой общей и левой наружной сонных артерий в противовес второму ускоренному периоду развития сонных артерий, для которого характерно увеличение наружных диаметров правой общей и правой наружной сонных артерий. Значимая разница средних значений внешних диаметров правой и левой общих, наружных и внутренних сонных артерий характерна для 4-го, 7-го, 10 месяцев развития и для периода новорожденности для общих сонных артерий; для наружных сонных артерий - для 4-го, 7-го, 9-го месяцев развития и для периода новорожденности; для внутренних сонных артерий - для всех месяцев развития.

Ключевые слова: общая сонная артерия, наружная сонная артерия, внутренняя сонная артерия, морфометрия, плодовый и ранний неонатальный периоды онтогенеза человека. 